\title{
EVALUATION OF BACTERIAL QUALITY OF GOAT'S MILK IN DUHOK PROVIDENCE
}

\author{
Issa M. Mohammed*, Jwan K. M. Al-Sulaivany** and Mahmoud A. Ayed** \\ "Dept. of Animal production, College of Agricultural Engineering Sciences, University of Duhok, \\ Kurdistan Region-Iraq \\ ${ }^{* *}$ College of Agricultural \& Forestry, University of Mosul-Iraq
}

(Received: October 13, 2021; Accepted for Publication: November 11, 2021 )

\begin{abstract}
A total of 102 samples of native goat's milk and local Maraz goat milk were collected from the district of Summel in Duhok governorate from various farms for the period of February, 1 up to 1 May, 2016. The aim of this study was to evaluate both types of milk bacteriologically. The results showed that Native goat or black goat milk samples were contaminated with different strains of bacteria; pollution percentages for the total bacterial count, Enterobacteriaceae and Staphylococcus aureus were $(41.17,13.72$ and $21.56 \%)$, respectively; and the same bacteria as averages were $\left(24 \times 10^{7}, 5.17 \times 104\right.$ and $\left.4.18 \times 10^{3} \mathrm{CFU} / \mathrm{ml}\right)$ respectively. The results of Maraz milk showed that the pollution percentages for the total of bacterial count, Enterobacteriaceae and Staphylococcus aureus were $(45.09,13.72$ and $15.68 \%)$, respectively; and as average were $\left(21.7 \times 10^{7}, 3.4 \times 10^{4}\right.$ and $\left.4.1 \times 10^{3} \mathrm{CFU} / \mathrm{ml}\right)$, respectively; while there were no Salmonella bacteria presence in the studied milk samples of both local and Maraz goats. While there were different strains of Enterobacteriaceae bacteria $(42.85 \%$ of $E$. coli I, $14.28 \%$ of $E$. coli II, $7.14 \%$ of $K$. pneumonia, $14.28 \%$ of $K$ Pneumoniae II, $7.14 \%$ of type $K$. oxtoca and $14.28 \%$ belong to type Shigella sp). The results of Staphylococcus aureus showed that they produce plasma coagulation enzyme as $100 \%$, catalase enzyme as $63.15 \%$, lecithinase as $84.21 \%$, gelatinase as $73.68 \%$ and enzyme alpha amylase as $89.47 \%$. In conclusion all studied samples of milk were free of Salmonella, but some studied samples contained strains of Enterobacteriaceae that is a bad indicator on the human, due to make illness.
\end{abstract}

KEY WORDS: Goat milk, Maraz milk, Bacteriological properties, Enterobacteriaceae, Staphylococcus aureus bacteria.

\section{INTRODUCTION}

$\mathbf{S}^{\mathrm{s}}$ heep and goats are the most important animals producing milk after dairy cattle in temperate areas and tropical (Albenzio and Santillo, 2011). The studied goats belong to two breeds, the first of which is the local black goat (Native goat) and the second is Maraz goat (Juma and Alkass, 2005). Maraz goats are located along the northern border of the Kurdistan Region of Iraq, and belongs to a hardy's breed. It is one of the distinctive types, because their hair is used in the Kurdish clothing industry that sold in high prices; in addition to its traditional advantages as milk and meat (Alkass and Merkhan, 2013). Goat's milk provides three important benefits, the first is for drinking (human consumption); the second feature is manufacturing goat's milk products, especially cheese; and the third benefit is that some people suffer from allergies due to drinking cow's milk (Haenlein 2004, Haenlein, and Wendorff,2006). Despite the great benefit, goat's milk, it can be easily contaminated or spoiled by improper production and storage (staying on the farm for a long time without properly preservation, or transporting it by contaminated utensils) as reported by (Metz et al., 2009). There are other factors that contribute to milk contamination, such as the unsanitary conditions in the farm (Son, et al., 2009). Due to the importance of food safety and consumer health as well as animal health protection, assessment of the microbiological situation and the presence of pathogenic bacteria in goat milk should be studied, to save healthy for animals and human.

Delgado-Pertinez et al. (2003) indicated that total bacterial count in goat's milk was $\left(4.81 \times 10^{5}\right.$ $\mathrm{CFU} / \mathrm{ml}$ ), also Kyozaire et al. (2005) were mentioned similar value $\left(4.68 \times 10^{5} \mathrm{CFU} / \mathrm{ml}\right)$; the higher value $\left(1.3 \times 10^{6}\right)$ was obtained by (Eshraga et al., 2011); while, the highest value was stated by (Abu Ghurra et al. 2013), where they reported a range $\left(2.6 \times 10^{6}\right.$ to $\left.81.5 \times 10^{8} \mathrm{CFU} / \mathrm{ml}\right)$. For Coliform bacteria, Chye et al., (2004) found that the E. coli population was more than $\left(12 \times 10^{6}\right.$ 
CFU/ml); while Elek et al. (2012) found that Escherichia coli and Klebsiella spp percentages in the goat milk samples were $20 \%$ and $22.5 \%$, respectively. For Staphylococcus aureus, Rahimi and Alian (2013) found that the infection rate of this bacteria was $7.5 \%$ in goat's milk; while Tarekne et al. (2015) reported the rate of infection as $47 \%$ or $\left(4.34 \times 10^{3} \mathrm{CFU} / \mathrm{ml}\right)$; however, the highest rate was observed by Jorgensen et al. (2005) whose indicated (96.2\%). In respect to Salmonella spp., Abu Ghurra et al. (2013) found through their study on cheeses made from sheep's milk that the infection rate of Salmonella spp., was 21.25\%; while Doskey (2000) indicated infection rate of yoghurt and cheese as zero; also Muehlherr et al. (2003) and Ekici et al. (2004), indicated the same last result (zero-contamination rate) for samples of goat's milk in different countries; while Saliq et al. (2010) recorded the moderate rates $(15 \%)$ of Salmonella spp., contamination in samples of fresh cheese made from goat's milk

The aim of this study was to investigate the bacterial contamination in milk of both native goat or black and Maraz, because they are the most important animals spread in the studied area.

\section{MATERIAL AND METHODS}

Studied samples: A total of 102 samples of goat's milk (Native + Maraz) aged 2, 3 and 4 years, were collected from several fields of Summel town- Duhok governorate-Kurdistan Region-Iraq.

Total aerobic bacterial count: The plate method that mentioned by Harrigan and McCance (1987) was followed using Nutrient Agar, for this bacterium.

Coliform count: Estimated number of coliform bacteria in one ml. of milk was done using surface inoculating technique as reported by Harrigan and McCance (1987) with McConkey agar medium.

Staphylococcus aureus count: The number of Staphylococcus aureus in one $\mathrm{ml}$ of milk was determined also using surface inoculating technique (Harrigan and McCance ,1987) with Mannitol salt agar.

Detection of the presence of Salmonella: Salmonella bacteria were detected according to the method that mentioned by (Harrigan and McCance ,1987).

Staphylococcus aureus diagnosis: It was diagnosed according to the method that mentioned also by (Harrigan and McCance ,1987).

Coliform Diagnosis: The method that described by the manufacturer of the diagnostic kit (BioMerieux) was followed for diagnosis using APi 20 E Kit.

\section{RESULTS AND DISCUSSION \\ Total bacterial count}

The number of positive samples in which aerobic bacteria appeared in native goat's milk was 21 out of 51 samples with a percentage of $41.17 \%$, however the number of positive samples in Maraz goat milk was 23 out of 51 samples with a percentage of $45.09 \%$, as shown in Tables 1 and 2 . As the minimum total bacterial count in native goat's milk was $1 \times 10^{6} \mathrm{CFU} / \mathrm{ml}$, while the maximum was $81 \times 10^{7} \mathrm{CFU} / \mathrm{ml}$ (Table 1 ), while the minimum total count of bacteria in Maraz goat's milk was $1 \times 10^{7} \mathrm{CFU} / \mathrm{ml}$ and the maximum was $54 \times 10^{7} \mathrm{CFU} / \mathrm{ml}$ (Table 2). It was found that these results are in agreement with the finding of Abu Ghurra et al. (2013), and are disagreed with that reported by (Delgado Pertinez et al., 2003; Kyozaire et al., 2005; Eshraga et al., 2011). The high contamination of milk with bacteria may be due to the high temperature, which provides a suitable environment for contamination or pollution of animals from the contaminated field floor that caused from animal waste and transmission the bacteria to the udder through the teat holes and even after cleaning the teat before the milking process, the bacteria remain inside these channels and contaminating the milk during the process of milking.

This study showed that the number of bacteria increases as the end of the milk season approaches (Figure 1), which may due to the spread of bacteria across an atmosphere that incubating them with the rise in temperature at the end of the milking season (Eshraga et al., 2011; Oliveira et al., 2011; Tarekne et al., 2015). Regarding the effect of the breed on the microbial content of the milk, the results indicated the same finding for both studied breeds (native goats and Maraz) as shown in Figure 2. In respect to the effect of age of does, this study illustrates the increasing of the microbial content in the milk as age increased (Figure 3), which may be due to the decrease in lactenin of the milk as animal aged (Tarekne et al., 2015). 
Table (1):- The presence of bacteria in native goat milk

\begin{tabular}{|c|c|c|c|c|c|c|}
\hline & $\begin{array}{l}\text { Number of } \\
\text { positive } \\
\text { samples }\end{array}$ & Percentage & Minimum & Maximum & Mean & $\begin{array}{l}\text { Standard } \\
\text { error }\end{array}$ \\
\hline $\begin{array}{l}\text { Total bacterial } \\
\text { count }\end{array}$ & 21 & 41.17 & $1 \times 10^{6}$ & $81 \times 10^{7}$ & $\begin{array}{c}24 x \\
10^{7}\end{array}$ & $\begin{array}{c}4.86 \mathrm{x} \\
10^{7}\end{array}$ \\
\hline Total Coliform & 7 & 13.72 & $3 \times 10^{4}$ & $9 \times 10^{4}$ & $\begin{array}{l}5.17 \\
\times 10^{4}\end{array}$ & $\begin{array}{c}8.37 x \\
10^{3}\end{array}$ \\
\hline $\begin{array}{l}\text { Staphylococcus } \\
\text { aureus }\end{array}$ & 11 & 21.56 & $1 \times 10^{3}$ & $8 \times 10^{3}$ & $\begin{array}{r}4.18 \\
\times 10^{3} \\
\end{array}$ & $\begin{array}{c}4.23 x \\
10^{2} \\
\end{array}$ \\
\hline Salmonella & 0 & 0 & & & & \\
\hline
\end{tabular}

Table (2): - The presence of bacteria in the milk of the Maraz goat

\begin{tabular}{|c|c|c|c|c|c|c|}
\hline & $\begin{array}{l}\text { Number of } \\
\text { positive } \\
\text { samples }\end{array}$ & Percentage & Minimum & Maximum & Mean & $\begin{array}{l}\text { Standard } \\
\text { error }\end{array}$ \\
\hline Total bacterial count & 23 & 45.09 & $1 \times 10^{7}$ & $54 \times 10^{7}$ & $\begin{array}{c}21.7 \mathrm{x} \\
10^{7}\end{array}$ & $3.9 \times 10^{7}$ \\
\hline Total Coliform & 7 & 13.72 & $2 \times 10^{4}$ & $6 \times 10^{4}$ & $3.4 \times 10^{4}$ & $6.1 \times 10^{3}$ \\
\hline $\begin{array}{l}\text { Staphylococcus } \\
\text { aureus }\end{array}$ & 8 & 15.68 & $1 \times 10^{3}$ & $1 \times 10^{4}$ & $4.1 \times 10^{3}$ & $1 \times 10^{3}$ \\
\hline Salmonella & 0 & 0 & & & & \\
\hline
\end{tabular}



Fig.( 1):-.Effect of time (weeks) on the percentage of milk contamination with some strains of bacteria

\section{Coliform bacteria}

As shown in Tables (1 and 2), the number of positive samples is 7 for the milk of both studied breed, with percentage of $13.72 \%$ for contamination. The minimum number of Coliform in native goat's milk is $3 \times 10^{4} \mathrm{CFU} / \mathrm{ml}$, and the maximum one is $9 \times 10^{4} \mathrm{CFU} / \mathrm{ml}$ (Table $1)$; while the minimum number of bacteria in Maraz goat's milk is $2 \times 10^{4} \mathrm{CFU} / \mathrm{ml}$, and the maximum one is $6 \times 10^{4} \mathrm{CFU} / \mathrm{ml}$ (Table 2). These results are in agreement with that indicated by (Muehlherr et al., 2003; Oliveira et al., 2011); and disagreed with that referred by (Silva et al., 2013; Foschino et al., 2002). The presence of such strain of bacteria is an indication of milk contamination with feces, and thus the presence of some strains leads to food poisoning due to its toxic secretions; then it decreases the quality of the product such as cheeses at low ambient temperatures, which may expose the product to rapid corruption (OIE, 2002).

\section{Staphylococcus aureus}

The results of Staphylococcus aureus bacteria count for both breeds are presented in Tables (1 
and 2). It could be observed that the number of positive samples is 11 for native goat's milk and
8 for Maraz goat's milk, with the contamination percentage of ( 21.56 and $15.68 \%$ ), respectively.

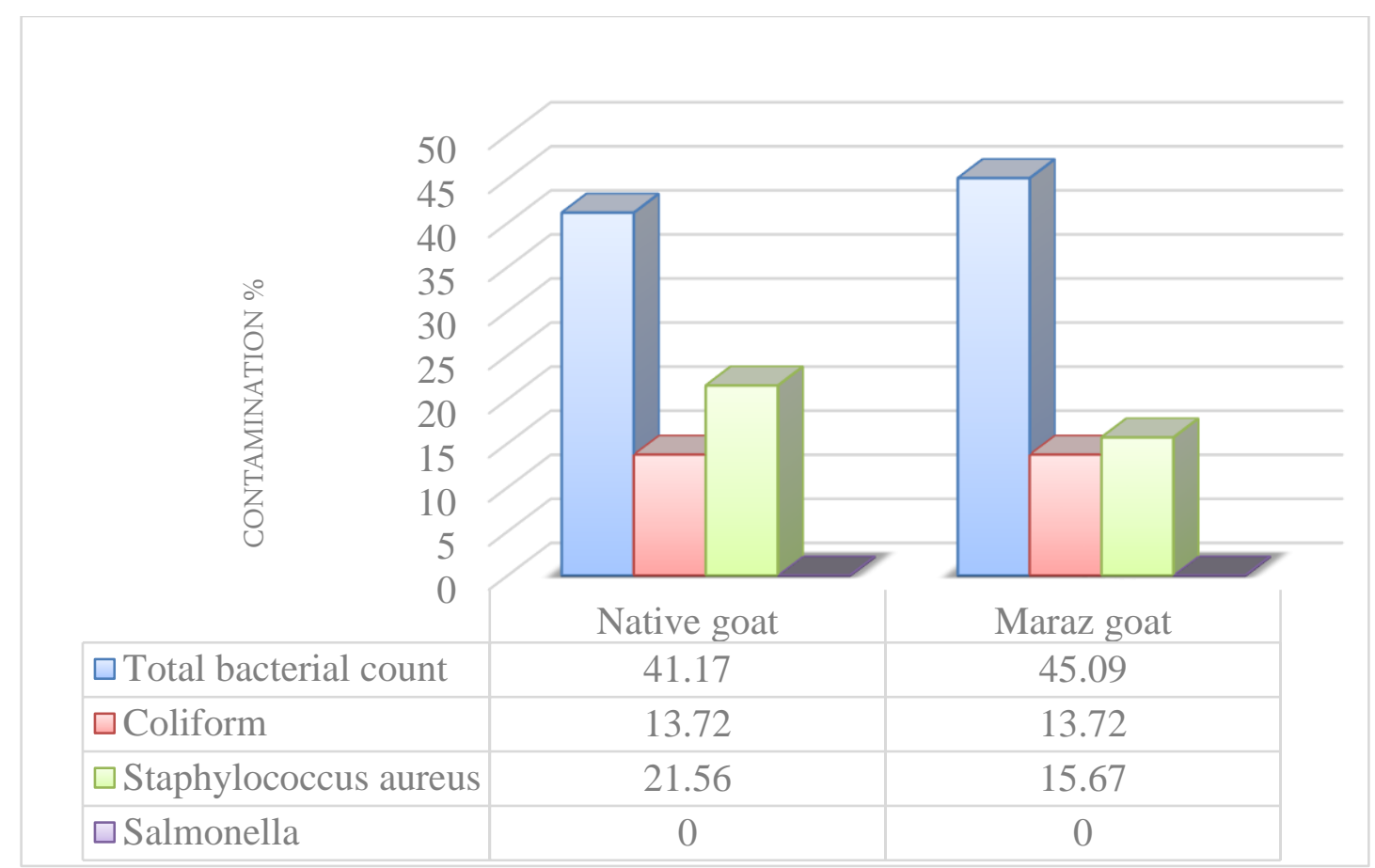

Fig.(2):-Effect of breed on the percentage of milk contamination with some types of bacteria

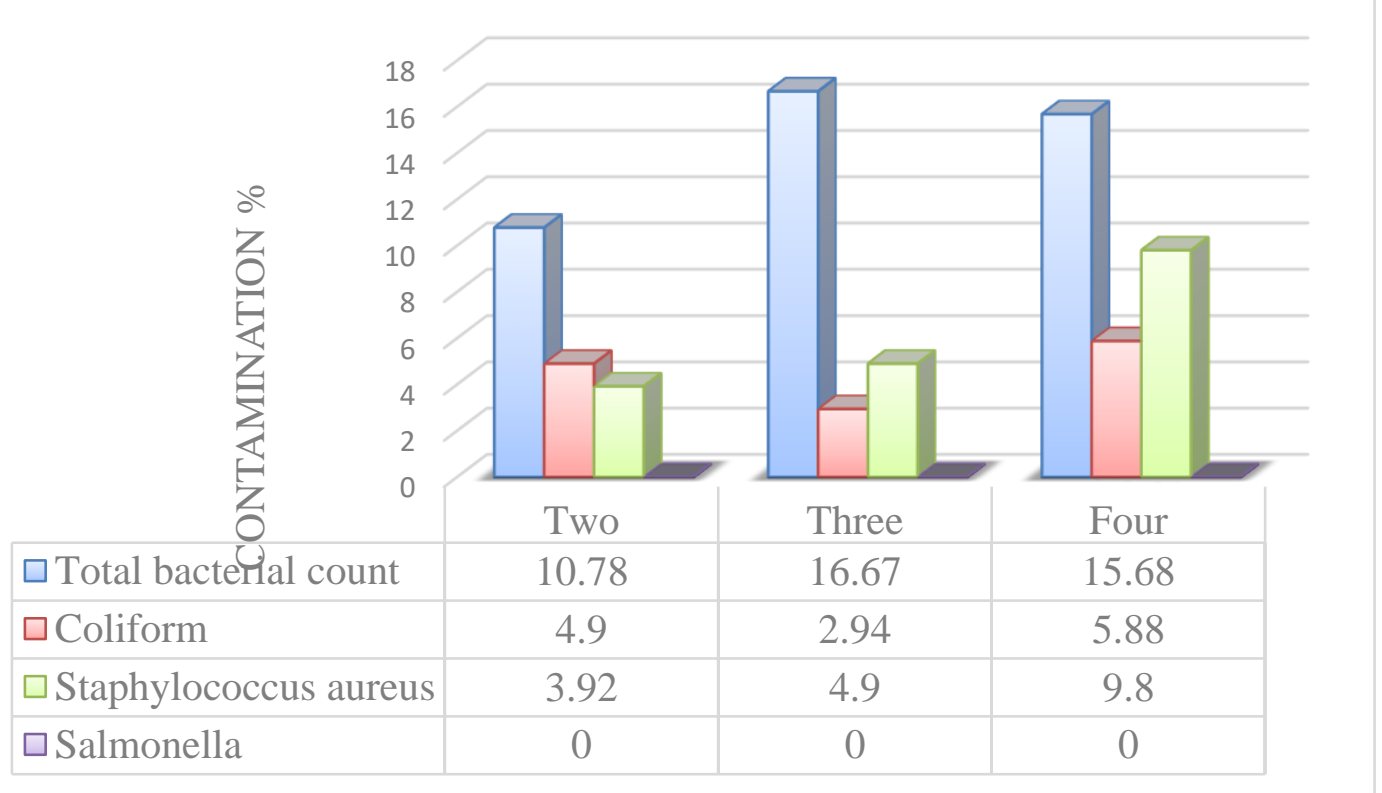

Fig.( 3):-.Effect of age (years) on the percentage of milk contamination with some types of bacteria

However, the number of this bacteria in native goat's milk as minimum is $1 \times 10^{4} \mathrm{CFU} / \mathrm{ml}$, and the maximum one is $8 \times 10^{3} \mathrm{CFU} / \mathrm{ml}$; while in Maraz goat's milk are $\left(1 \times 10^{3}\right.$ and $1 \times 10^{4}$ $\mathrm{CFU} / \mathrm{ml}$ ) for minimum and maximum count, respectively. These findings are in agreement with that mentioned by (Little and De Louvois, 1999; Deinhofer and Pernthaner, 1995); and disagreed with that reported by (Foschino et al.,
2002; Al-Nassrawi and Al-Ramahi, 2007; Tarekne et al., 2015). Milk contamination with such strain of bacteria is an indication of mastitis (Leitner et al., 2004), in addition to the ability to secrete toxins in foods, because the presence of $(0.5-1)$ million cells per gram or in one milliliter is sufficient to cause serious intestinal poisoning (Stewart, 2003). 


\section{Salmonella spp.}

It is clear from Tables (1 and 2) that there is no infection in the studied samples, and this result is in agreement with that recorded by (Doskey, 2000; Ekici et al., 2004; Muehlherr et al., 2003), and disagreed with that of (Abu Ghurra et al., 2013; Saliq et al., 2010).

\section{Diagnosis of Staphylococcus aureus bacteria}

Isolating Staphylococcus aureus has been done because its presence in the food is dangerous to the health of the consumer (Doskey, 2000). A total of 19 out of 102 samples of native goat and Maraz goat's milk were contaminated with Staphylococcus aureus (Table 3). As diagnostic characteristics of Staphylococcus; the positive isolates were 19 with rate of (100\%) plasma coagulant and catalase enzymes, but 12 of them were lecithinase with rate of $(63.15 \%), 16$ isolates were hemolytic enzymes with rate of $(84.21 \%)$, 14 isolates were producing gelatinase enzyme with rate of (73.68) and 17 isolates were producing alpha amylase enzyme with rate of $(89.47 \%)$ as shown in Table (3).

Table( 3):- Some diagnostic and physiological characteristics of Staphylococcus aureus bacteria isolated from milk of both studied breeds

\begin{tabular}{ccccccc}
\hline & $\begin{array}{c}\text { Plasma } \\
\text { coagulant }\end{array}$ & Lecithinase & Catalase & $\begin{array}{c}\text { Hemolytic } \\
\text { enzymes }\end{array}$ & Gelatinase & alpha amylase \\
\hline $\begin{array}{c}\text { Number of } \\
\text { isolations }\end{array}$ & 19 & 12 & 19 & 16 & 14 & 17 \\
\hline Percentage $\%$ & 100 & 63.15 & 100 & 84.21 & 73.68 & 89.47 \\
\hline
\end{tabular}

\section{DIAGNOSIS OF ENTEROBACTERIACEAE}

A total of 14 samples out of 102 contained enterobacteria. Six isolates which represent (42.85\%) were belong to E. coli-type I, two isolates $(14.28 \%)$ were belong to E. coli-type II, one isolate $(7.14 \%)$ was belong to type $K$. pneumoniae I, two isolates (14.28\%) were belong to type $K$. pneumoniae II, one isolate $(7.14 \%$ ) was belong to $K$. oxtoca and two isolates (14.28\%) were belong to Shigella. $s p$.

It could be noticed from Table 4, that the discrepancy in the ability of isolates of coliform bacteria in goat's milk, to ferment different sugars (according to biochemical analyzes using the APi 20 E Kit method), the most frequent type of these bacteria are 6 isolates that represent $(42.85 \%)$ of E. coli type I, and the lowest frequent (7.14 \%) are both K. pneumoniae I and K. oxtoca. As it can be noted from the same Table that all isolates are negative for the amino acid (arginine), as well as for fatty acids, ester and acetyl-glucose-aminide; also, all isolates were negative for the proline assay and positive for the sorbitol assay; for lysine, all isolates were positive except for Shigella. $s p$, which was negative with rate of $(14.28 \%)$. While those species differed in their fermentation of maltose sugars, aldehydes and xylose, as it was found that 4 isolates that represent $(28.57 \%)$ fermented maltose, also the same number and rate fermented aldehydes and xylose. As for the rest analysis, it appeared from Table 4, that all species are negative for the urea test, except for $K$. pneumoniae II, which was positive and represent (14.28\%). Regarding ornithine, the positive isolates number were 9 isolates (64.28\%); and finally, adonitol and tryptophan tests appeared the number of positive samples as 2 and 11 isolates with rate of (14.28 and $78.57 \%$ ), respectively. 
Table (4):-The biochemical types of (14) isolates of Enterobacteriaceae isolated from both breeds of goat's milk

\begin{tabular}{|c|c|c|c|c|c|c|}
\hline Number of isolations & 6 & 2 & 1 & 2 & 1 & 2 \\
\hline Type of bacteria & E.coli-I & E.Coli II & K. pneumoniae I & K. pneumoniae II & K. oxtoca & $\begin{array}{l}\text { Shigella } \\
\text { sp. }\end{array}$ \\
\hline Percentage \% & $42.85 \%$ & $14.28 \%$ & $7.14 \%$ & $14.28 \%$ & $7.14 \%$ & $14.28 \%$ \\
\hline Urea & - & - & - & + & - & - \\
\hline Arginine & - & - & - & - & - & - \\
\hline Ornithine & + & + & - & - & + & - \\
\hline Lysine & + & + & + & + & + & - \\
\hline Fatik Tayol & - & - & + & - & - & - \\
\hline Esteric fatty acids & - & - & - & - & - & - \\
\hline Aldehydic sugars & - & - & + & + & + & - \\
\hline Sorbitol & + & + & + & + & + & + \\
\hline $\begin{array}{ll}\text { Nitrophenyl } & \text { D-B } \\
\text { Glucuronide } & \\
\end{array}$ & + & - & - & - & + & - \\
\hline $\begin{array}{l}\text { Nitrophenyl } \\
\text { Calctoside }\end{array}$ & + & + & - & + & + & - \\
\hline $\begin{array}{ll}\text { Nitrophenyl } & \text { D-B } \\
\text { Glucoside } & \\
\end{array}$ & - & - & + & + & + & - \\
\hline $\begin{array}{ll}\begin{array}{l}\text { Nitrophenyl } \\
\text { Xyloside }\end{array} & \text { D-B } \\
\end{array}$ & - & - & + & + & + & - \\
\hline $\begin{array}{l}\text { Acetyl D-B Glucose } \\
\text { Aminide }\end{array}$ & - & - & - & - & - & - \\
\hline Maltose & - & - & + & + & + & - \\
\hline $\begin{array}{l}\text { Proline-B } \\
\text { Naphthylamide }\end{array}$ & - & - & - & - & - & - \\
\hline $\begin{array}{l}\text { Gama - clatamic B - } \\
\text { naphthylamide }\end{array}$ & + & - & + & + & + & - \\
\hline $\begin{array}{l}\text { Pyrrolidonil-B } \\
\text { Naphthylamide } \\
\end{array}$ & - & - & + & + & - & - \\
\hline Adonitol & - & - & + & - & + & - \\
\hline Treptophan & + & + & - & - & + & + \\
\hline
\end{tabular}

\section{CONCLUSION}

It could be concluded from the present investigation that all studied samples of milk were free of Salmonella bacteria, and contained less of dangerous bacteria such as Staphylococcus aureus and E. coli; but goat's milk contained more Staphylococcus aureus than Maraz goat's; and at the same time some studied samples contained strains of Enterobacteriaceae that is a bad indicator for the human, due to make illness.

\section{REFERENCES}

Abu Ghurra, S.; S. Saliq and A. Abu Younes. (2013). Diagnosis of Salmonella SPP bacteria isolated from white cheese made from sheep's milk. Damascus University Journal of Agricultural Sciences, Volume 29, Issue 1, Pages 129-141.

Albenzio, M. and A. Santillo. (2011) Biochemical characteristics of ewe and goat milk: Effect on the quality of dairy products. Small Ruminant Research. (101): 33-40.

Alkass, J.E.; and K.Y. Merkhan. (2013). Meriz goat in Kurdistan region/Iraq: A Review. Adv. $j$. Agric. Res. Vol 1(007), pp. 105-111.

Al-Nassrawi, H. A. and H. M. Al-Ramahi. (2007). Prevalence of goat's subclinical mastitis caused by coagulase negative Staphylococci spp. in Al-Diwanyia province. The Scientific Journal of Vet. Med. Vol. 6.No. 1
Deinhofer, M. and A. Pernthaner. (1995). Staphylococcus spp. as mastitis-related pathogens in goat's milk. Veterinary Microbiology 43(2-3):161-166.

Chye, F. Y.; A. Aminah and M. A. Ayob. (2004). Bacteriological quality and safety of raw milk in Malaysia. Food Microbiology 535-541.

Delgado-Pertinez, M.; M. J. Alcalde; J.L. GuzmanGuerrero; J.M. Castel; Y. Mena and F. Caravaca. (2003). Effect of hygiene-sanitary management on goat milk quality in semiextensive systems in Spain. Small Ruminant Research 47: 51-61

Doskey, I. M. M. (2000). Microbiological study on local yoghurt and soft cheese Dohuk city, Master's Thesis/ College of Agriculture/Dohuk University.

Ekici, K.; H. Bozkurt and O. Isleyici (2004). Isolation of some pathogens from raw milks of different milk animals. Pakistan journal of nutrition 3 (3): 161-162.

Elek, J.; K. Al-Zamili; Y. Zughayer, and A. Adel Saber. (2012). Biological study of Escherichia coli and Klebsiella spp bacteria present in local goat milk on the outskirts of Kut city, Al-Furat Journal of Agricultural Sciences-4(2):173-179.

Eshraga A.; A. Eissa; E. Elfadil; B. Babiker; A. Abu ElGasim; and C.D. Yagoub. (2011). Physicochemical, microbiological and sensory properties of Sudanese yoghurt (zabadi) made 
from goat's milk. Animal Production Science 51(1):53-59.

Foschino, R.; A. Invernizzi; R. Barucco; and K. Stradiotto. (2002). Microbial composition, including the incidence of pathogens, of goat milk from the Bergamo region of Italy during a lactation year. Journal of Dairy Research 69(2):213-225.

Haenlein, G. F. W. (2004). Goat milk in human nutrition. Small Ruminant Research 51: 155163.

Haenlein, G. F. W. and W. L. Wendorff. (2006). Sheep milk: production and utilization of sheep milk. In: Handbook of Milk of Non-bovine Mammals (eds Y.W. Park and G.F.W. Haenlein), Pp:137-194. Blackwell Publishing Professional, Ames, IA.

Harrigan, W.F. and E. M. McCance. (1987). Laboratory methods in food and dairy microbiology 7th ed. Acad. Pr. (Lond) LTD.

Jorgensen, H.J.; Mork, T.; Hogasen, H.R. and Rorvik, L.M. (2005). Enterotoxigenic Staphylococcus aureus in bulk milk in Norway. Journal of Applied Microbiology. 99(1):158-166.

Juma, K.H. and J.E. Alkass. (2005). Native goats of Iraq: A review. Dirasat. 32: 180-188.

Kyozaire, J.K; C.M. Veary; I.M. Petzer; and E.F. Donkin (2005). Microbiological quality of goat's milk obtained under different production systems. J. S. Afr. Vet. Assoc. 76 (2): 69-73.

Leitner, G.; U. Merin, and N., Silanikove. (2004). Changes in milk composition as affected by subclinical mastitis in goats. J. Dairy Sci. 87, 1719-1726.

Little, C.L. and J. Delouvois (1999). Health risks associated with unpasteurized goats and ewes' milk on retail sale in England and Wales. A PHLS Dairy Products Working Group Study. Epidemiol Infect 122(3):403-408.

Metz, I.V.; V. Michel; C. Delbes. and M. C. Montel (2009). Do milking practices influence the bacterial diversity of raw milk. Food Microbiology 26:305-310.

Muehlherr, J.E., C. Zweifel.; S. Corti. A. J. E. Blanco. and R. Stephan. (2003). Microbiological quality of raw goat's and ewe's bulk-tank milk in Switzerland. Journal of Dairy Science 86(12):3849-3856.

OIE (Office International des Epizooties) (2002). "Pathogenic micro-organisms Milk and Dairy Products the Situation in France and Europe" 16: 452-471.www.oie.int.

Oliveira, C. J. B.; E. R. Hisrich; J. F. P Moura.; P. E. N. Givisiez; R. G. Costa; and W. A Gebreyes (2011). On farm risk factors associated with goat milk quality in Northeast Brazil. Small Ruminant Research, Amsterdam.98(1-3): 6469.

Rahimi, E and F. Alian (2013). Presence of enterotoxigenic Staphylococcus aureus in cow, camel, sheep, goat, and buffalo bulk tank milk Veterinarski Arhiv. 83 (1): 23-30.

Saliq, S.; S. Abu Ghurra, and A. Abu Younes. (2010). Detection of salmonella bacteria in fresh Syrian white cheese, Damascus University Journal of Agricultural Sciences. Volume 26 Issue 1, Pages 305-321.

Silva, G. S.; I. S. Ferrari; C. D. A. Silva; W. L. G. ALmeida Junior; K. F. Carrijo; M. M. Costa; A. E. V. N. Silva; and F. S. Dias (2013). Microbiological and physical-chemical profile of goat milk in the Semiarid region of the San Francisco valley. Vet. Not., Uberlândia. 19 (1): 14-22.

Son, I.; V. Kessel.; J. A. S. and J. S. Karns (2009). Genotypic diversity of Escherichia coli in a dairy farm. Foodborne pathogens and Diseases 7:837-84.

Stewart CM. (2003). Staphylococcus aureus and staphylococcal enterotoxins. Ch 12 In Hocking AD (ed) Foodborne microorganisms of public health significance. 6th ed, Australian Institute of Food Science and Technology (NSW Branch), Sydney, p. 359-380.

Tarekgne, E.; S. Skeie ; K. Rudi ; T. Skjerdal and J. A. Narvhus (2015). Staphylococcus aureus and other Staphylococcus species in milk and milk products from Tigray region, Northern Ethiopia. African Journal of Food Science. 9(12): 567-576. 